\title{
CLAUDE LANZMANN'S THE FOUR SISTERS (2017) ON TELEVISION
}

\author{
Sue Vice \\ University of Sheffield \\ s.vice@sheffield.ac.uk
}

\begin{abstract}
This article analyses Claude Lanzmann's final work, The Four Sisters (2017), in the context of its being edited from the outtakes of Shoah (1985) for broadcast on the Arte television channel. It argues that the distinctive features of the film, including its form as a quartet of self-contained interviews, absence of location footage and reliance on certain kinds of shot construction and mise-en-scène, arise from this televisual production context, as well as seeming to mark an ambivalent effort on the director's part to redress his earlier work's focus on male testifiers.
\end{abstract}

Keywords: Claude Lanzmann, Holocaust, Shoah, female survivors, television

\section{Introduction}

Claude Lanzmann's final release, The Four Sisters (2017), was produced by the French company Synecdoche for broadcast on the French/German television channel Arte. It consists of footage from Lanzmann's interview outtakes, recorded between 1978 and 1979, which were excluded from his 1985 documentary Shoah. More than 35 years later, extracts from this archival material were edited into the form of a quartet of encounters with female Holocaust survivors. This work therefore constitutes, as its producer David Frenkel observes, "for the first time in [Lanzmann's] career ... a TV series," while its exclusive focus on women's experience is likewise unprecedented in the director's oeuvre. $^{1}$

The film is composed of self-contained interviews, with the testifiers Ruth Elias, Ada Lichtman, Paula Biren and Hanna Marton (Figure 1). 


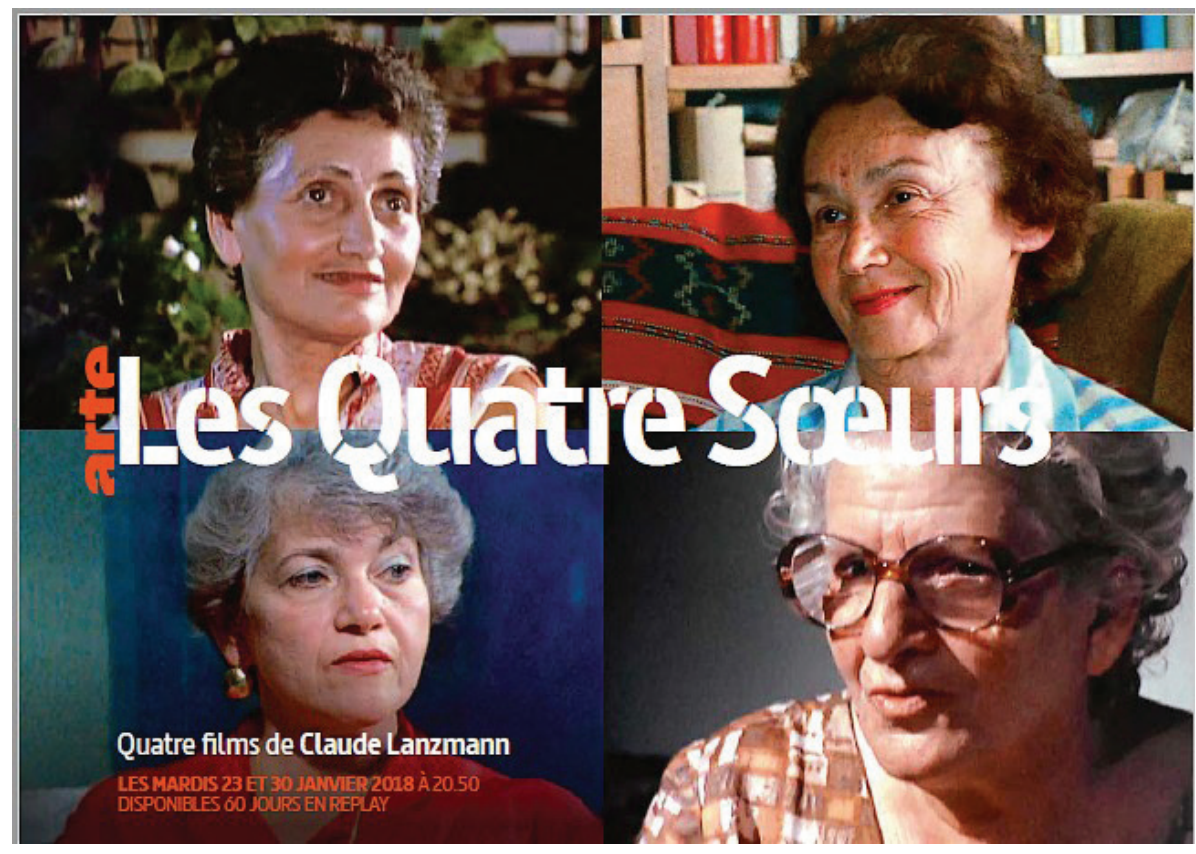

Figure 1. Advertising the Arte broadcast of The Four Sisters, 2017.

The relatedness of the four encounters has, I will argue, implications beyond that of the title's phrasing. While the allusion to Anton Chekov's 1901 play Three Sisters suggests a familial and generational likeness, ${ }^{2}$ these interviews are, rather, united by their exposing the gendered nature of racial systems of power. The film lays bare these strategies through the four testifiers' accounts of their varied experiences as women. These include undergoing expulsion, segregation and enslavement, exertion of control over reproduction as well as over life itself, attempts to use the victims as tools in their own destruction, and the efforts of those targeted in this way to save themselves. The four testimonies thus address questions central to the subordination and attempted destruction of individual bodies, and, through them, the body of an entire people constructed as other. Recent critical work on the relationship between Lanzmann's archive of excluded interviews and his finished films, including Shoah itself but also the subsequent releases, includes crucial analysis especially of the uncut footage of the present four interviews, with the effect of emphasizing decisions made in constructing the final version of The Four Sisters. ${ }^{3}$ The belated editing and broadcast of these four interviews enables an extended meditation on the ways in which racial difference is constructed and policed in gendered terms.

Lanzmann's concerns, as these emerge in Shoah and in the footage which was excluded to generate that film's final form, are with the "small," concrete details relating to the processes of genocide in the death camps, rather than "larger questions" about the origins and system of the antisemitic ideology that underpinned it. ${ }^{4}$ Therefore, although startling instances of the Nazis' belief in their own conspiracy theory about Jewish power emerge in his outtake interviews, Lanzmann's emphasis in Shoah lies rather on the practice of the mass murder that resulted. ${ }^{5}$ Indeed, a similar focus to that of the final film on the nature of the killing process, and eyewitness responses to it, is evident in The Four Sisters, since the encounters with Ruth Elias and Ada Lichtman centre on the interviewees' experience in the camps of Auschwitz and Sobibór.

However, the fact that all four interviewees are women, by contrast to the emphasis placed on male Sonderkommando testifiers in Shoah, and that the television format of The Four Sisters enables the use of extended individual encounters rather than the detailed montage of the released film, establishes a new emphasis on questions of the particularity of women's "vulnerability" during the Holocaust years, and their being targeted as a "distinct biological and racial group." Each of the four interviewees gives a remarkable account of their experience of wartime hardship in the ghettos and camps of the Nazis' racialized regime, yet, despite the claims of reviewers and the director himself, the 
film's impression is not that of a celebration of personal survival or continued vitality against almost insuperable odds. Rather, in the film as a whole, the nature of "genocidal patriarchy" and the extremity of its exclusionary practices is given testimonial and visual form. ${ }^{7}$

\section{Editing The Four Sisters}

The Four Sisters consists of newly edited material taken from the 220 hours of footage excluded from Shoah, all of which is held in Lanzmann's archive at the United States Holocaust Memorial Museum and made available online. ${ }^{8}$ Each of the film's constituent testimonies possesses its own subtitle. In 'The Hippocratic Oath,' Ruth Elias describes her imprisonment in Theresienstadt followed by the death of her child in Auschwitz; in 'The Merry Flea,' titled after the deceptively jocular name given by the SS to their living-quarters, Ada Lichtman recalls her experience of slave labour in the death-camp of Sobibór; 'Bałuty' consists of Paula Biren recounting her time in the Łódź Ghetto, including recruitment to the Jewish police, before being deported to Auschwitz; and in 'Noah's Ark,' Hanna Marton describes escape with her husband from occupied Hungary on the so-called Kasztner Train. As the use of subheadings suggests, the interviews take the form of individual chapters within a single text. The emphasis on women's bodily experience is expressed through a focus on the spatial (for Lichtman and Biren), conceptual (Elias and Marton) and bodily mechanisms of biopolitical domination.

While very short extracts feature in Shoah from Lanzmann's encounters with Elias and Biren, none of the footage of Lichtman and Marton appears at all. Such choices emphasise the fact that these four interviews, like all those featured in or excluded from the assemblage of testifiers' voices that constitutes Shoah, were evaluated in relation to the final film's focus on the process of genocide in the death-camps of Poland. Thus, Elias's brief utterance in the final release was the result of radical cutting to centre on her description of arrival at Auschwitz and inability to believe that mass murder was taking place. Biren's appearance in Shoah is even briefer in its focus on her disinclination, as her family's sole survivor, to return from the USA to her native Poland, as she puts it: "What would I see? How can I face it?"9 The atypical and fleeting nature of these moments in relation to the whole interview in each case sheds light on Lanzmann's priorities for Shoah through their differences from the extended accounts in The Four Sisters.

By contrast to Elias and Biren, Lichtman's and Marton's stories were entirely excluded from Shoah, because they represent facets of the Holocaust years which do not feature in the finished film, respectively armed resistance and self-rescue. Lichtman escaped from Sobibór at the time of the revolt, but, although she and her husband Itzhak are mentioned by Yehuda Lerner in his account of the uprising in Lanzmann's film Sobibor, October 14, 1943, 4pm (2001), Lichtman is not questioned here about her role in the resistance. ${ }^{10}$ The interview's emphasis lies instead on a confrontation between her prisoner perspective on the camp and that of its deputy commandant, Gustav Wagner, through the prism of gender. Marton's is one of several encounters about the fate of the Jews of Hungary which Lanzmann filmed but did not use in Shoah, including those with the survivor Hansi Brand and Israeli lawyer Shmuel Tamir. Like Marton's, these interviews centre on the question of negotiations with the Nazis for the Jews' release, undertaken by the rescue committee members Brand and her colleague Rezső Kasztner. Lanzmann is at pains to withhold the kind of censorious judgement on wartime actions that these negotiations have provoked, declaring in an interview that none of the Jewish leaders of the era can be described as collaborators. ${ }^{11}$ Indeed, The Four Sisters exposes instead the imposition of moral dilemmas, unwinnable in this genocidal context, such as that of urging 'rescue through work', embodied by the Łódź Ghetto leader Chaim Rumkowski about whom Lanzmann questions Biren, and that of selective rescue, typified by the Kasztner Train initiative. Although the interviews have been described as united by the expression of the painful recall of "traumatic complicity"12 and survivor guilt, they can even more compellingly be viewed as centring on gendered techniques of racial control and genocidal murder. 
S. Vice, Claude Lanzmann's The Four Sisters (2017) on Television

\section{Childbirth: "The Hippocratic Oath"}

The interview with Ruth Elias, filmed in the garden of her Tel Aviv home against a backdrop of greenery that contrasts with the bleakness of her story (Figure 2), gives individual expression to the Nazis' regulation of reproduction, by one of the very few of those who gave birth in Auschwitz to have survived. The excisions made to the original almost 3.5-hour interview in order to create 'The Hippocratic Oath' streamline Elias' narration by halving its running time to 89 minutes. ${ }^{13}$ However, Elias's is the longest of all the quartet's interviews, in part because of the extremity of its personal account of survival and atrocious death.

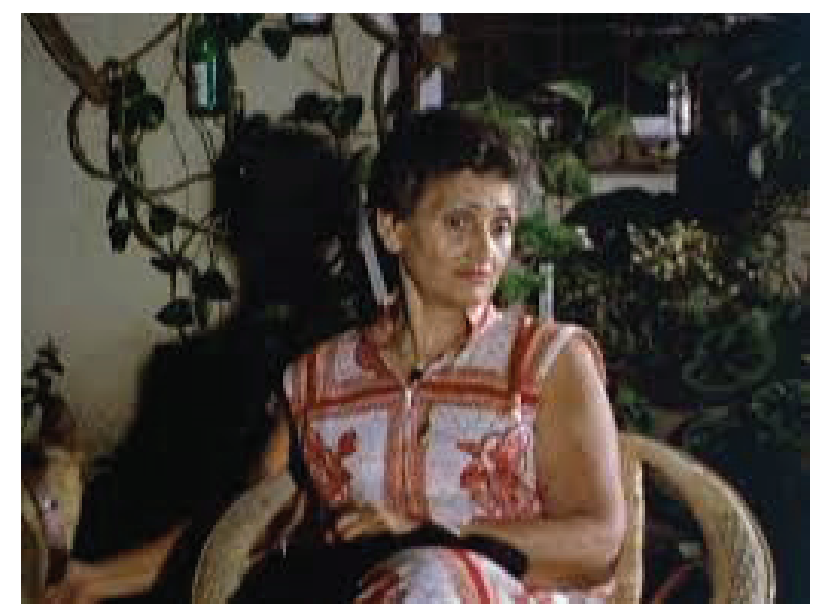

Figure 2. Ruth Elias in her garden, Tel Aviv.

Elias's experience, almost too troubling to summarize, of 'research' at the hands of the infamous Nazi doctor Josef Mengele in Auschwitz included being forbidden to feed her new-born daughter. Elias recounts that the sympathetic woman doctor, Maca Steinberg, who came to her aid felt unable, because of the Hippocratic Oath's code of medical conduct prohibiting harm, to administer a fatal dose of morphine to the dying child, forcing the new mother to do it herself. Critics have argued that Elias's account of infanticide is not only what makes her story so striking and painful to watch, but is also the reason for its exclusion from Shoah. ${ }^{14}$ Its absence has been seen to support the foundational argument made by Marianne Hirsch and Leo Spitzer about the minor and also mythically inflected role of women in the film. ${ }^{15}$ Yet Elias's interview is sufficiently significant to be the first of The Four Sisters' instalments, and it sets the tone for the entire documentary. The ghetto song 'The Terezín March' which Elias plays on an accordion during the encounter is used as the extradiegetic theme throughout, and each subsequent interview is introduced by this 'musical testimony' which brings the past into the present. ${ }^{16}$

According to an important essay by Debarati Sanyal on the original interview before the release of The Four Sisters, Elias's account of "the gendered bodily reality of childbirth and infanticide in Auschwitz," and the psychological survival she demonstrates in its aftermath, is "far more difficult for Lanzmann to co-witness' than the sequences of "masculine psychic destruction"” that we see in Shoah. ${ }^{17}$ But rather than shying away from the "taboo of maternal infanticide" embodied here, the interview in its broadcast form has been edited to place this act centre-stage. ${ }^{18}$ This is evident at all levels, from the interview's title, 'The Hippocratic Oath,' to the way in which the editorial decisions put emphasis on particular aspects of the mise-en-scène, dialogue and the often silent, listening presence of Lanzmann himself. The director's face is shown only in the form of reverse shots, acting as a figure of the hyper-vigilant auditor constructed by the interview (Figure 3). 


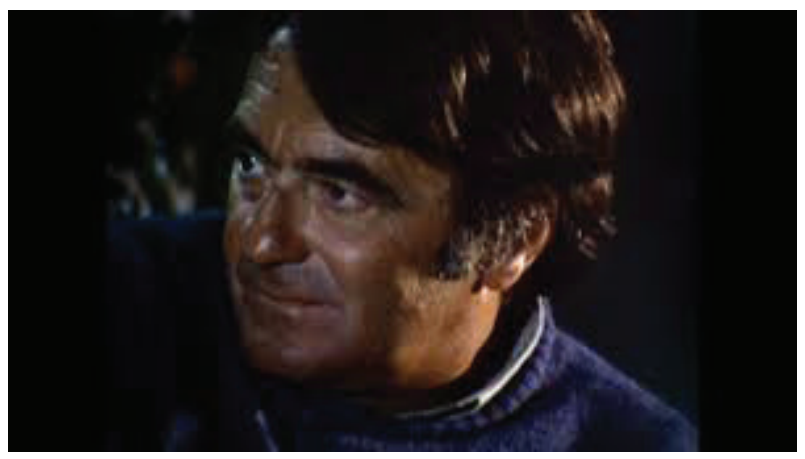

Figure 3. Lanzmann as auditor.

Lanzmann makes only one comment during the entire narration of the baby's death when Elias, in her distress during the interview, can only recall the effect of the doctor's instructions in German, and seems to search her mind for the English word:

ELIAS: She started to talk to me, into me. The more she talked, the less I had any Widerstand ....

\section{LANZMANN: Resistance.}

ELIAS: ... until I made it. I gave the injection to my child.

While it might feel uncomfortable to describe the act of infanticide itself in terms of resistance, ${ }^{19}$ Lanzmann's intervention, uttered in a low voice, allows Elias to overcome her sudden resistance in the moment of filming to relating the conclusion to a story she has up to that moment wanted to tell.

Most tellingly, cut from the edited version is Elias's account of meeting her second husband, later the father of her two sons, at the forced labour camp of Taucha that was the final location of her wartime ordeal. The exclusion of Ruth and Kurt Elias meeting each other, however significant in its camp setting and for her later life, ensures that the emotional energy and philosophical significance of the baby's death is not dissipated.

The interview's title introduces the gulf between the Hippocratic pledge that a physician will "help the sick, and ... abstain from all intentional wrong-doing and harm," to its polar opposite, that of Mengele's practice of assault and murder, in which the prohibition against "abusing the bodies of man or woman, bond or free," is honoured only in its being shockingly breached. Indeed, behaviour of which this is an extreme kind, as legitimized by a biomedically enforced hierarchy, has prompted the ethical 'reckoning' that characterizes recent revisions of the oath to prohibit 'discrimination and bias. ${ }^{20}$ In the present interview, the Hippocratic Oath is explicitly invoked by Steinberg as she assists Elias to kill her daughter for the sake of her own life. This reveals, in the moral inversion represented by the Auschwitz world where healing and killing had changed places, that birth entailed death, the preservation of one life the destruction of another. However, the title's reference is not just to the Jewish doctor's adherence to the oath, and its necessitating murder by a mother to save herself, but to the system that had repudiated its fundamental declaration of care. Mengele, whose acts are the antithesis of the Hippocratic injunction to offer 'help,' typifies the ethical reversal by which killing was viewed as a 'therapeutic imperative' to rid the 'Aryan' collective of a disease, so that the deaths of members of 'the inferior race' were deemed necessary to make life 'healthier and purer' for the dominant other. ${ }^{21} \mathrm{His}$ claim of medical investigation is itself a distortion of any medical goal or method of research, constituting rather an assertion of racial domination through 'medicalized' murder. ${ }^{22}$ 
As Charlotte Garson argues, the horrifying nature of Elias's story exists in 'tension' with the animation of her delivery, including even her claim of the Nazis, "They succeeded. They destroyed us." ${ }^{23}$ Rather than concluding with the post-war depression into which she was cast by the loss of her entire family, as well as her child, the interview has been edited so that its ending acknowledges instead a 'reconfigured' maternity ${ }^{24}$ through Elias's being reunited in Israel with Maca Steinberg, the prisoner-doctor from Auschwitz, who is, as Elias puts it, "my mother today."

\section{Sewing and Dolls: "The Merry Flea"}

A more oblique but visually multifaceted representation of the Nazis' 'manipulation of reproductive lives' is evident in Lanzmann's interview with Ada Lichtman about her experience in the camp of Sobibór. ${ }^{25}$ In this case, we encounter the image of 'Aryan' child-birth being valorised in the setting of a death-camp, as witnessed by someone marked out for murder as a racial inferior.

The broadcast version of the encounter with Lichtman has been edited down from the almost three hours of the original into 52 minutes, with a particular emphasis on her activity of sewing, to convey the slave-labour in which she was forced to engage during the war. ${ }^{26}$ Like the haircutting by the former Treblinka camp barber Abraham Bomba during his interview in Shoah, the rhythm and action of sewing enables Lichtman to return to the scenes of the past. Although it might seem a creative and reparative act, sewing in this context is rather an adjunct to theft and murder. This is conveyed by the segment opening with a disorientating close-up on what turns out to be a collection of plastic dolls lying on a table. The sequence is taken from a concluding silent reel that was shot for the purpose of such intercutting. Although Lichtman describes dressing dolls in SS uniform, the sole recognizable costume is that of Red Riding Hood, an embodiment not only of the dark meaning of children's stories, in this case a fairy-tale in which a young girl witnesses the murder of her grandmother, but also one that draws attention to the fictive elements of this representation of the real (Figure 4).

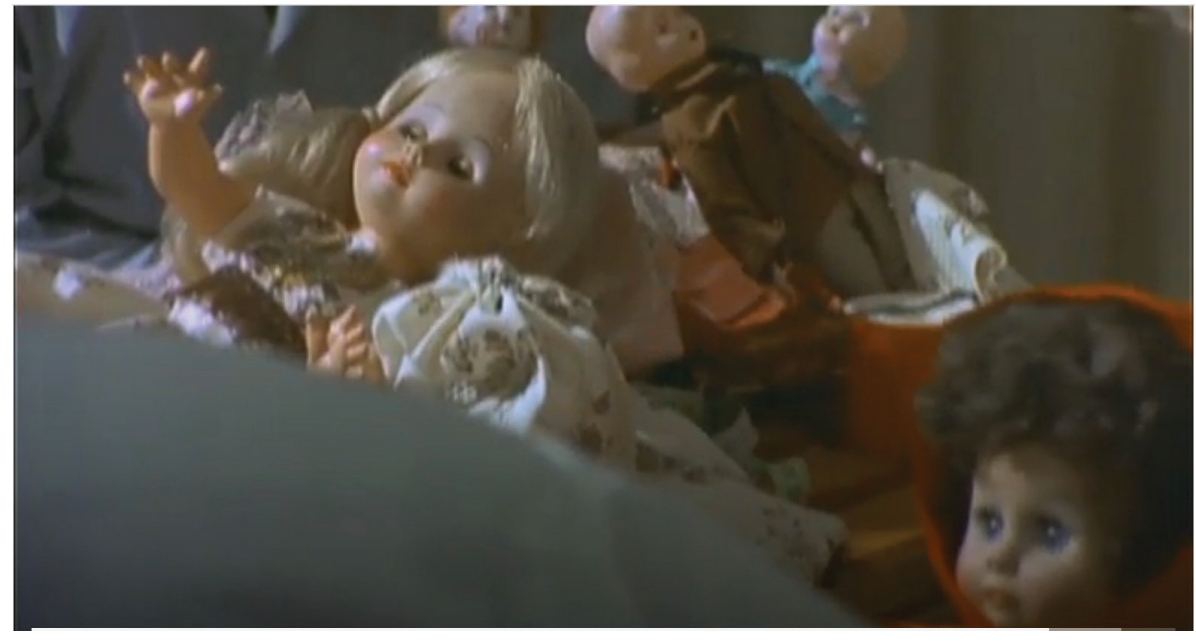

Figure 4. Opening shots of dolls including Red Riding Hood.

The imagery of the piled-up bodies condenses in the viewer's mind the children with the toys stolen from them, while Lichtman's description of the dolls as 'beautiful and big ones, broken, different', makes them 
embody a terrible category-error. In stark contrast to what we hear of the treatment of people arriving at the camp, who were stripped of their belongings before being killed, Lichtman recounts that 'we cleaned and washed them, then we dressed each doll, sewed different clothes for her'. Lichtman's description of Rushka, a ten-year-old girl who also worked in the laundry, reveals another in a series of dehumanizing and uncanny substitutions that are conveyed by the imagery of toys. Rushka's youth and her 'racial' status is emphasized in the terms of her resembling 'a doll, with beautiful long black hair', as well as by her wish to play with the toys before they were given away. Lichtman holds a dark-haired doll as she describes this evidence of the child's vulnerability, adding that she never learnt what happened to Rushka after the uprising in Sobibór.

The doll signifies the wartime atrocities while conveying the absence of any image of them. At the same time, the dolls' pink plastic bodies are an extra signifier of the question of 'whiteness' in relation to the film's concern with racial crimes. ${ }^{27}$ However, the film's emphasis on systems of racial control might lead the viewer to recall the address given by the African American writer W.E. B. Du Bois after his visit to Warsaw in 1952, where the ruins of the former ghetto prompted him to conclude that "the race problem in which I was interested cut across all lines of color," as well as those of religion or "physical and racial characteristics." 28 A multidirectional perspective like Du Bois's is enabled by the film's combination of specificity with much broader questions of power and domination.

Lichtman recounts how, during the war, the stolen toys were taken by SS officials as family gifts when they went home on leave, Lanzmann's surprise at the acceptability to the Nazis of Jewish children's belongings emphasizing the priority of objects over people that characterizes the interview. Indeed, Lichtman's account of such appropriation emphasizes the blurring of difference between toys and children, as she puts it, of the camp's deputy commandant, Gustav Wagner: "They did not take only toys ... Wagner for example took the basket of a ... new-born child, and a blanket ... to be cleaned for taking home."

This detail conveys the Nazi notion of racial purification that demanded the supplanting of one group by another, just as the original occupant of the baby basket was to be replaced by Wagner's child. If "futurity is at the heart of biopolitical practice," as Sara Smith and Pavithra Vasudevan argue, then the future planned for here is one consisting of the obliteration of an entire people by means of murder, the prevention of their reproduction and of any possibility of the enactment of 'revenge' by successive generations. ${ }^{29}$ The murder of children that this racial fantasy entailed is continued in Lichtman's story of contravening the camp rules, after she was caught eating an illicit pancake when Wagner visited the laundry. But rather than being 'sent away' to her death, as she and her workmates feared, Lichtman was taken to the camp storeroom to choose from among the looted goods some clothes for Wagner's wife. Lichtman starts by ventriloquizing his words to her:

LICHTMAN: [He] said: Ada, take for me things to wear, and he told me I should take clothes for his wife. Then he told me his wife is expecting a baby ... He would ask, well, is that nice? I would say yes, and he would take it.

The significance of this episode is signalled by the fact that, in its final form, Lichtman's words and presence are carefully put together to allow for the return of doll imagery into the mise-en-scène. Rather than using synchronous dialogue from the moment in the interview when she recounted Wagner's actions, we hear Lichtman's account while seeing a section of eye-catching footage taken from the concluding silent reel, an effect enabled by her averted face. The camera makes a 360-degree turn to reveal Lanzmann's presence, filmed over the shoulders of Lichtman and her husband. The fact that the dolls' clothing obscures the director's face makes their visual and symbolic importance unmistakeable (Figure 5). 


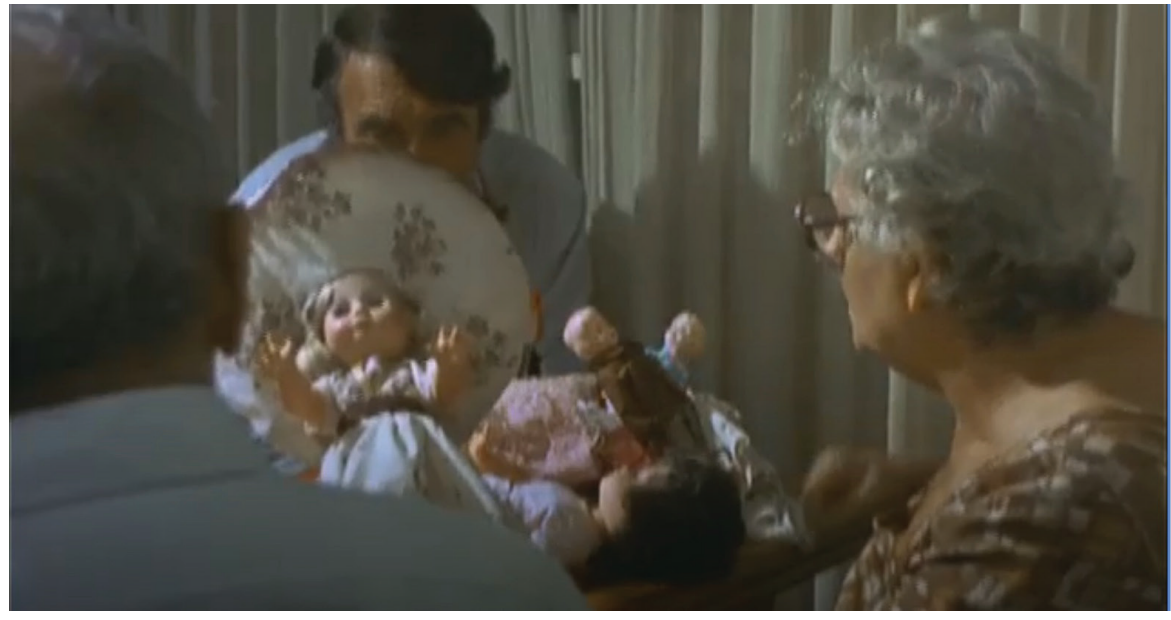

Figure 5. Dolls blot out Lanzmann's face.

Although it dramatizes the 'luck' that contributed to Lichtman's survival, conveyed by the tears of relief shed by her fellow workers on her return, this episode represents a confrontation between the opposite sides of a murderous regime: an SS officer, of whom Lichtman says everyone was afraid, asking the advice of a Jewish woman whose death was deferred only by her work as a slave, about the 'Aryan' reproduction that was contrastingly encouraged and celebrated.

'The Merry Flea' ends with a laconic exchange, its apparent abruptness the result of being cut down sharply from a longer dialogue that occurred earlier in the original interview:

LANZMANN: It's unbelievable, dressing dolls in a death camp.

LICHTMAN: Unbelievable - it was all unbelievable.

As well as making clear the significance of the dolls' prominence in the mise-en-scène, this final exchange raises the notion of deception, highlighting the difficulty not only of perceiving but also of understanding the fact that genocide was taking place.

\section{The Ghetto Police: "Bałuty"}

While Elias's and Lichtman's interviews address the regulation of reproduction, that with Paula Biren centres on the extreme spatial segregation of the wartime ghetto, named thus to imply Jewish self-governance but established to enable the control and deportation of its inhabitants. ${ }^{30}$ Although it has been halved in length from just over two hours to 64 minutes, the section included in The Four Sisters retains the emphasis of the original interview on Biren's experience in the Łódź Ghetto during the period before her deportation to Auschwitz, her impressions of the ghetto leader, Chaim Rumkowski, and her own actions, including as a recruit to the ghetto police force. ${ }^{31}$ The interview's title, 'Bałuty', referring to the district of Łódź in which the ghetto was located and which Biren describes as 'the slums of the city', focuses on the responses of the inhabitants to circumstances in which they were, as she puts it, both "jailed and dehumanized." While Lanzmann's admission that he had been unable to interview male members of the Łódź Ghetto police suggests that theirs would be the real story of this 'tragedy' of enforced moral compromise, the emphasis of the title makes clear that this section has a communal focus, with Biren speaking on behalf of a vanished body of people. 
Biren's testimony sketches out the spatial reality of the ghetto, including the combined psychological and practical effects of its version of segregationist violence. While it cast those forced to live in that space, in Biren's words, as "dangerous, different, nothing," its sealed nature 'as the most cut off' of all the Polish ghettos meant that contact with the outside world, including the possibility of escape or the smuggling of food or weapons, which took place in the Warsaw Ghetto, was minimal. The photographs that appear in the encounter with Biren, in the form of full-screen versions of wartime scenes, represent a change from Lanzmann's strategy in Shoah of avoiding archival imagery. The photographs substitute for the unused location reels of Łódź filmed by Lanzmann's crew in the late 1970s, now held in the USHMM archive, their Cold-War-era appearance making them, unlike those of Biren's words which they were to accompany, anachronistic for a film broadcast in the twentyfirst century. The photographs, showing the wooden bridge connecting parts of the ghetto and a sign reading 'Wohngebiet der Juden: Betreten Verboten' [Residential Area for Jews: Entry Forbidden], reveal the manipulation of the 'ordinary' cityscape to produce "distinct 'Jewish' and 'non-Jewish' space." ${ }^{2}$ In their status as historical rather than personal images, these photographs establish a narrative that conflicts with those post-war judgements levied against the ghetto inhabitants which are broached in the interview, at the same time acting as a cover for cuts to the soundtrack.

Biren's role in the police, and the distress that voicing this 'untouchable' issue, as she calls it, causes her in the present, shows the success of the Nazis' efforts within the sequestered spaces of ghettos and camps to spread the guilt of complicity to their victims. As Katarzyna Person argues in a history of the Warsaw Ghetto police, they were judged then and now as 'traitors to their people' for enforcing the laws that were 'imposed' on them by the German administration. ${ }^{33}$ This section of Biren's interview takes place in a setting very different from that of the opening sequence, in which she and the director walk together along the Florida shore towards the camera, the sight of the sea and a ship on the horizon giving an impression of natural open space far removed from the constrictions of the ghetto (Figure 6).

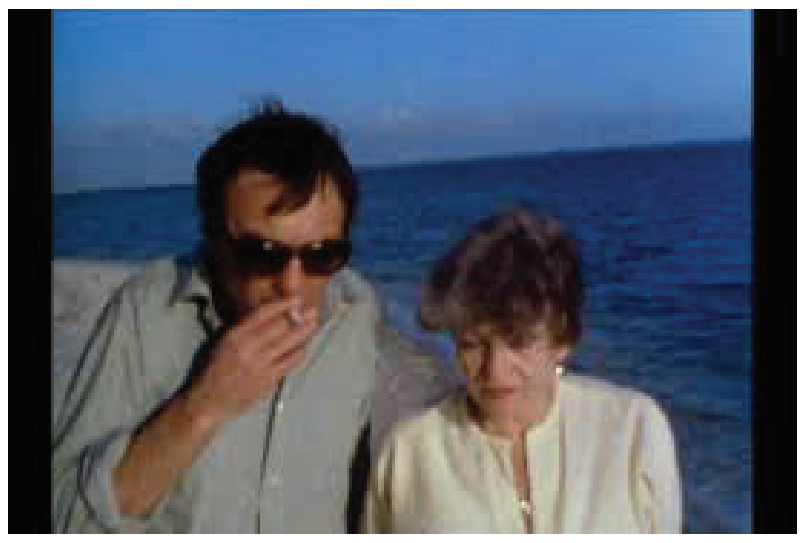

Figure 6. Lanzmann and Biren on the beach.

Rather, the majority of Biren's account is recorded in an impersonal hotel room where close-ups reveal her carefully composed but ill-at-ease demeanour (Figure 7).

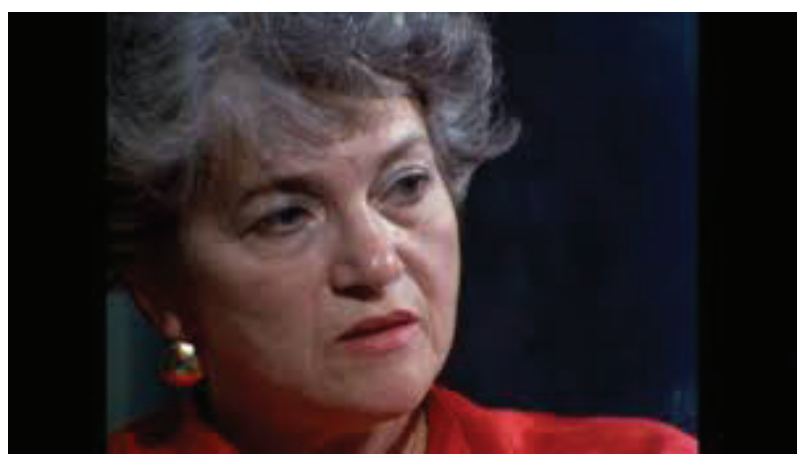

Figure 7. Close-up on Biren, hotel room. 
In this setting, Biren's description of her job making raincoats for the Wehrmacht after graduating from Rumkowski's high school prompts the director to ask:

LANZMANN: Yes, and the boys?

BIREN: Well, for the boys he had other jobs. ...

LANZMANN: You don't want to say it?

BIREN: No. That's for other people to say.

LANZMANN: May I say it?

BIREN: No.

Yet Biren's dramatic reluctance even to name the existence of what it becomes clear is the Jewish Police, testifying to its contested history, exists in relation only to its male members with whom the service is more usually associated, since it is quickly followed by her satirizing her own 'noble' job: "I was recruited to be a police officer. Very funny."

Biren's fraught admission is present for the sake of Lanzmann's wider interest in Jewish reactions to their plight in Nazi-occupied Europe, meaning that even the unedited interview centres on her experiences in the Łódź Ghetto and not those in Auschwitz. Despite the director's esteem for Raul Hilberg, the form and variety of his interviews conflicts with the historian's harsh verdict that Jewish wartime responses consisted only of "an attempt to avert action and, failing that, automatic compliance with orders." ${ }^{34}$ In Biren's case, while Lanzmann puts it to her that "the ghetto machinery" itself, encompassing the Judenrat or Jewish Council, the forced labour that benefited the German wareffort and the Jewish police units implementing the laws regulating the racially segregated space, constituted "a tool for extermination," she asserts that, apart from suicide, "you can say there was no other choice." Lanzmann's statement about the former Jewish policemen that, "I didn't want to accuse them - it was the other way round: to get people to see why Jews enlisted. Can you help me to understand?," represents a mixture of performance with sincerity on his part. It contributes to the interview's mode of post-war and meta-cinematic reflection on the process of the painful recall in which the Jewish police, responses to ghettoization and survival itself are still held, and the shame of accusations of cooperation, complicity or worse, in the process of the subjugation of those very people.

Biren observes that, "until a few years ago, I would not talk - I feel too guilty, too ashamed," imagining that "I did wrong, that I'm alive, my family is not - I delivered them to the Germans." This moment could be seen as a stage in the externalizing of traumatic memory, particularly in its concluding with Biren's placing responsibility rather on "the others, everybody that participated ...the Germans, all Europeans." Such a working-through in a filmed interview is of a kind that Lanzmann has been accused of demoting in favour of the acting-out of past affronts. ${ }^{35}$ The slow pace of any equivalent working-through in the public realm, including the restoration of humanity to those, such as the Jewish police, who were the Nazis' "tools and victims," is evident in Person's continuing to insist in the present on the importance of understanding the motivation and conscience of those individuals, just as Lanzmann did to Biren nearly 40 years earlier. ${ }^{36}$

However, Biren's distress at the 'untouchable issue' relates to her survival more generally. It was not as a member of the women's squad of the Jewish police but in relation to a decision she took at the time of the ghetto's liquidation that her family should go into hiding which makes her feel she 'delivered' them to their deaths. They were found and sent to Auschwitz, rather than Terezín, which she later discovered was the original transport's destination. As Biren says to Lanzmann, "so you can imagine ... what I went through. It was my decision not to go there ... what would be if I decided differently? Maybe someone would survive." The interview ends not with the general reflections on the ghetto that conclude the unedited version, but with an avowal of displacement that originally took place earlier, redoubling our sense of Bałuty as a site of tainted spatial memory. Biren voices her 'pain' at feeling 'banned' from Poland twice over, 
S. Vice, Claude Lanzmann's The Four Sisters (2017) on Television

first by the Germans and then by the Poles in the post-war period, and her final words are a lament expressed as a maternal loss: "Polish was my mother tongue. I have forgotten much of it."

\section{Blood for Goods: "Noah's Ark"}

Hanna Marton's interview embodies the survivor guilt that seems to link all four encounters, as well as the confrontations by each eyewitness with insoluble ethical conundrums arising from the individual's relation to the community in a genocidal context. In Marton's case, such a dilemma is one about which Lanzmann gives his decided views elsewhere, for instance in an interview with the historian Yehuda Bauer, concerning the so-called Kasztner Train rescue. Through negotiation with Adolf Eichmann, in the latter's role as overseer of the process of deportation from Hungary, Kasztner and his colleagues in the Aid and Rescue Committee gained agreement towards the war's end to what was supposed to be a trial rescue. It was envisaged as the precursor to a more extensive plan in which the Germans would be supplied by the Allies with material for their war effort in exchange for Jewish lives. The notion's ethical horror is clear in Eichmann's description of it as trading 'Blood for Goods.' Although the instance of the Kasztner Train, the only such transfer to take place, was the means of saving the lives of Marton and her husband, among 1684 other Jewish passengers, the circumstances of the rescue and the role of Kasztner himself continue to be debated even in the present.

Much of the encounter with Marton takes the form of Lanzmann's posing a series of questions about the contrast between the train which eventually took her from her hometown of Cluj to Switzerland in 1944, and the fate of over 400,000 Hungarian Jews who were transported on quite different journeys to their deaths in Auschwitz that year. While never stating the critical arguments made against Kasztner explicitly, Lanzmann solicits Marton's response to them quite directly, unlike his interview with Biren about her membership of the Jewish police. The encounter has been edited to enhance the impression of a dialogic exchange of views by cutting out the more leading of Lanzmann's questions, as well as the figure of Francine Kaufmann, the translator between Marton's Hebrew and Lanzmann's French, to increase the viewer's sense of an unmediated encounter. ${ }^{37}$ Lanzmann's ability to speak English, as he does with both Elias and Biren, and German, with Lichtman, allows him to interact with them in a direct fashion that only the absence of translation in Marton's case can match. The reliance on extended close-ups of Marton's face means that we are not usually aware of those moments when her gaze is directed at Kaufmann rather than at Lanzmann. Almost all medium shots or two-shots in which it is seems clear that she is looking at someone other than the interviewer have been cut out, allowing for the naturalization of any remaining instances (Figure 8), while Lanzmann is always shown from the side, as was the case in the original version.

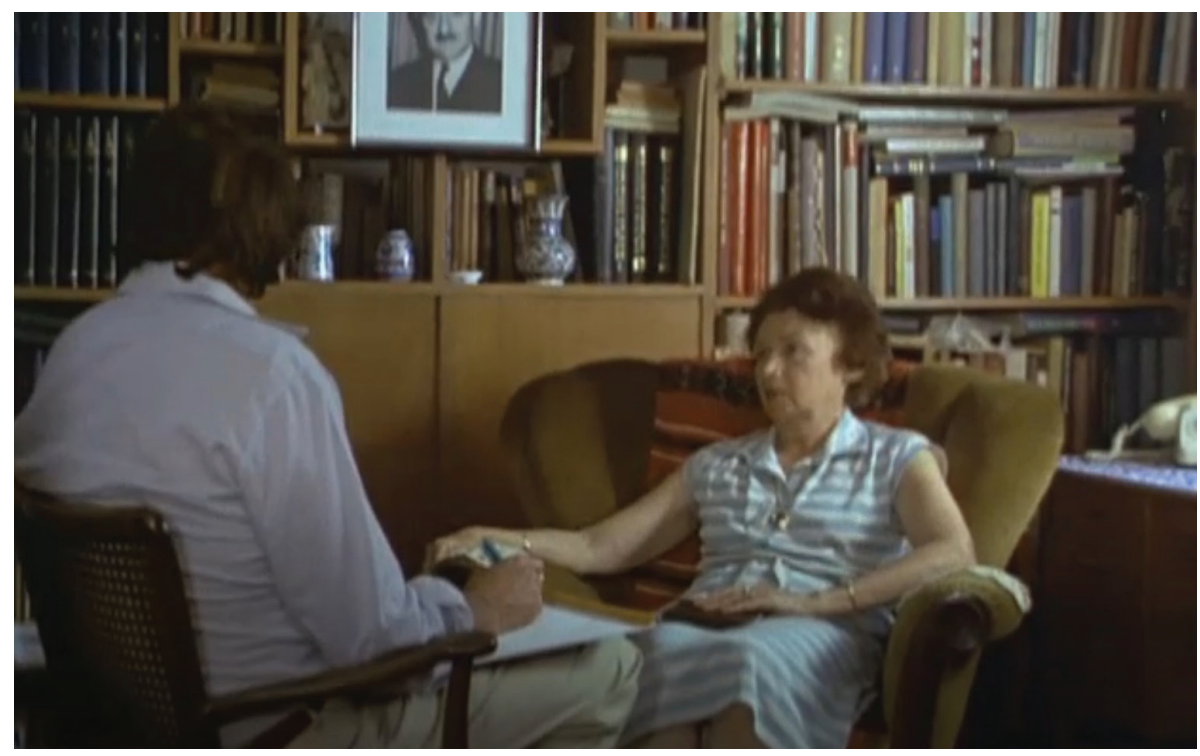

Figure 8. Lanzmann and Marton look at the unseen (and unheard) translator. 
Other changes to the mise-en-scène and soundtrack in order to suture over the translator's absence include the introduction of new elements, including a map of Cluj, photographs of its cityscape and of train tracks, over which we hear Marton's description of her hometown as the "humanist city par excellence," although she 'cursed' it when she left on the Kasztner Train. The translator's absence renders Marton's testimony more 'fluid' and suitable for television broadcast, in Kaufmann's approving description of her own removal. ${ }^{38}$

Despite these radical changes, the director's critical view of the rescue's selective nature seems evident, even if his scepticism has the effect of increasing our sense of there being no other options. The interview's title, 'Noah's Ark', like that of 'The Hippocratic Oath,' is inflected with historical irony. However, where the terrible consequences of allegiance to the eponymous oath in Elias's case make it convey only horror at the plight of the victims of the Nazi 'myth of racial superiority,' 39 in this segment there is more ambivalence in its addressing what Lanzmann calls 'the tragedy of choice,' one arising from the illusion of different courses of action being available. Lanzmann's phrase is an allusion to the practical and moral pitfalls of attempting to save or rescue individuals within the 'trap situation' of the Jews in occupied Europe, where, according to Zygmunt Bauman, "everything the Jews did to serve their own interest brought the Nazi objective somewhat nearer to full success." 40 Indeed, Bauman's contention that the modern state's suppression of morality in the service of bureaucratic rationality reached its apogee in the Nazi genocide, and extended even to its victims, appears to be an approach akin to Lanzmann's in his questioning the ethical basis of the Kasztner rescue. However, even if Lanzmann's perspective has elements in common with Bauman's on the Nazis' successful solicitation of the 'cooperation of the victims,' his own cinematic practice reinstates awareness of the ideological power of eliminationist antisemitism and of a context in which international efforts to offset it were absent.

The 'Noah's Ark' title of Marton's interview draws on Kasztner's use of the phrase to invoke the Biblical story of apparently miraculous salvation in the face of oncoming disaster. Yet, as the director emphasizes, it also implies the need for selecting those to be saved, based on a representative sample, or, as he puts it, a 'cross-section' of the community. In Lanzmann's use of the Biblical Ark imagery, God's ordering Noah to save a pair of each species of animal to ensure the continuation of his creation is an analogy for Kasztner's eye to a communal future by choosing between categories of people on the grounds of their familial or political standing. In the director's words, Kasztner "had to select the representatives of the Jewish people and of the elite." The implication is not only that, in the Biblical story and Kasztner Train alike, those not given shelter were left to perish, but also that the real-life rescue parallels the Ark story of choice made for a social vision to be attained through a version of biological engineering. ${ }^{41}$ In this sense, it is implied that a shadow version of the Nazis' murderous obsession with population control emerges in the form of the very efforts taken to evade it. Lanzmann's words on this occasion sound as if the director is indebted to Hannah Arendt's likewise contrasting the small number of those saved by Kasztner's initiative with the staggering total of those killed, despite his distancing himself in his autobiography from what he calls her partial and uncompassionate analysis. ${ }^{42}$ In filmic terms, the director's blunt challenge to Marton on these grounds seems designed to prompt her return to the moment of experiencing moral horror in 1944:

LANZMANN: When this transport of 1684 ... privileged Jews, left Budapest ... did you know ... that already 350,000 Jews from the Hungarian provinces had been sent to Auschwitz and that they had already practically all been gassed?

Lanzmann's summary of other responses to the impossibility of saving the community as a whole, or undertaking any action beyond individual rescue or suicidal rebellion, concludes with his quoting for Marton's consideration the view that, since "one does not have the right to choose who shall live and who shall die," then "it is better that everyone die." This challenge to the discourse of individual rescue, one prioritized in Holocaust history and education, enhances our sense of the intractability of the situation. However, the very posing of such a question to Marton compromises its rhetorical force, since it seems too much to expect her, or indeed the viewer, to assent to a view which would have entailed her own death. Indeed, only she, as the 'living example' of Kasztner's success, can return to the past in which such events took place. Marton recounts an exchange between acquaintances from Cluj and her father, who was imprisoned in the ghetto of Nagyvárad: 
MARTON: [They said], 'We can tell you that she is in a train headed for Budapest

and from there, she will go to Palestine'. Then my father said, 'Now I no longer care

about my own fate, I accept it, the important thing is that she is alive'.

LANZMANN: What was your father's fate?

MARTON: I am the sole surviving member of my family.

Lanzmann's request for clarification is followed by a pause as Marton composes herself, emphasizing the discomfiting nature of recalling her father's assent to the selectivity of rescue in the light of his death. Marton's utterance that follows - "I always ask myself the question: 'why just me?"'- gives a present-time form to the conundrums raised by the wartime rescue. The question extends beyond her own family to all those whose lives were not saved, and beyond this context to matters of choice and decision-making in relation to triage more generally, particularly where, as in the case of contemporary efforts to revise the Hippocratic Oath, implicit or explicit practitioner bias might exist. ${ }^{43}$

Lanzmann's opposition to the Kasztner Train's reliance on identifying and saving only "the privileged," as he puts it, emerges in relation to a version of the discourse of regulated reproduction, as addressed during the interviews with Elias and Lichtman, in its relevance to the Ark analogy. In the phrasing from Genesis 6:19, the animals to be taken into the Ark included breeding pairs, "two of every sort ... they shall be male and female." Lanzmann's questions to Marton arise from his mistrust of a cultural equivalent to this invocation of biological reproduction. The notion of 'every sort' to be placed in the Ark relies on the pre-ordained nature of distinctions between species, as well as between the sexes for the sake of future populations. Such an invocation here implies a connection with those notions of racial hierarchy which are, as Bauman points out, explicitly present in the zoologist Carl Linnaeus' taxonomy that distinguishes not only between animals on the basis of species but also between humans in terms of race. ${ }^{44}$ Indeed, the dialogue between interviewer and interviewee about decisions over who should be included in this 'slice of the Jewish population of Hungary' on the Kasztner Train, at the level of individuals and their affiliation or profession, takes on an uncanny resemblance to the categorization of the Ark's animals by 'sort':

LANZMANN: [Dr Hamburg] was a Zionist but wasn't he, at the same time, a distinguished oculist?

MARTON: Yes, yes, a distinguished oculist.

LANZMANN: There was the architect Thomas Blum, the pianist Dezső Ernster ....

MARTON: No, no pianists.

LANZMANN: Ah yes, I am confused, opera singer, isn't that so? There were also orphans?

Lanzmann's mention of the 'orphans,' and his adding an apparent wish to be reassured that other groups, such as 'the Jewish proletariat,' were included, is itself a distraction, since it is not the composition of the list of train passengers, but the existence of such a list at all, that is at stake. Marton's insistence that 'working people' were indeed on board, including the upholsterer "who made the armchair on which I am presently seated," brings these questions into the present of the interview's mise-en-scène. Yet it does not forestall Lanzmann's seeming to wonder aloud, in asking her whether "Kastner went too far ... he crossed a line that, perhaps, he shouldn't have crossed?"

If this implies that Kasztner had taken on a version of the division of people into those who would live or die according to arbitrary measures, then Marton, who does not shy away from admitting to her own disquiet at the selective nature of the rescue, gives a riposte that seems to restore responsibility back to where it belongs: "what always bothers me is that people forget ... it's the Nazi system that forced people to choose." 


\section{Conclusion}

While Shoah's centring on genocide is evident in its focus on journeys to and killing in the death-camps in Poland, The Four Sisters represents the murderous outcome of the Nazis' ideology from the specific perspective of female eyewitnesses. For Elias and Lichtman, a focus on gender division itself generates the interviews' engagement with women's work, their bodies and childbirth. The murder of children as this appears in both cases confirms the presence of a genocidal intent, as well as provoking its intended victims' comprehension of events in these terms. This is a moment of epistemological revolution which Lanzmann is often keen to retrieve, not least for the sake of determining whether understanding the existence of a genocidal goal altered reactions on the part of individuals or leaders. In the case of Biren and Marton, it seems that, at the time of filming, Lanzmann would have preferred to interview male witnesses, respectively members of the Jewish police and Marton's late husband Eduard, under whose photograph she sits (Figure 8) and from whose wartime diary she frequently quotes. However, Biren and Marton's testimonies offer the unusual perspectives of a woman police recruit and the wife of a 'fatalist' who accepted rescue on the Kasztner Train as 'destiny,' without which the film could not have taken its final female-centred form.

The remastering for television of material for which cinematic release had been envisaged demanded for The Four Sisters certain kinds of post-production alteration on the part of Lanzmann and his editor Chantal Hymans, while also enabling the introduction of new emphases and techniques. The combination of broadcast with philosophical concerns occurs here in relation to the underrepresented category of female witnesses, prompting Lanzmann's claim of The Four Sisters that 'television is the best medium' for the quartet of women's voices. ${ }^{45}$ By this he seems to mean that each witness is visible for longer stretches than anyone in Shoah, and that the quartet form surpasses that of his other releases centred on single testifiers. The effect of uninterrupted utterance in The Four Sisters is enhanced by the absence of location footage, which would have required material to be gathered from at least four different countries, including the present-day Czech Republic, Poland, Romania and Hungary. The awkward transitions within utterances that are therefore evident throughout all four encounters, whether arising from cuts to the interviews or jumps between the original 11-minute film reels, are less disguised, yet also less perceptible, on the small screen by contrast to the cinema. Rather than being 'minimally edited,' or resembling more a 'document' than documentary, as critics have suggested, The Four Sisters has been carefully crafted to give such an impression. ${ }^{46}$

The film's notable features, including Lanzmann's focus 'on the faces of his subjects', and formal differences from his other Holocaust-related works, were consistently highlighted by reviewers on its release. ${ }^{47}$ Although these observations did not include mention of The Four Sisters' having been made for television, the aspects identified seem precisely to arise from this context, in which our expectations that 'intimate relations' with the viewer will be established by means of prioritizing close-ups and dialogue over imagery are fulfilled. ${ }^{48}$ Thus, in contrast to the cinematic Shoah, the present film is characterized by an 'unadorned' look in the absence of landscape footage, the placing of the four interviews in a series rather than use of montage or cutting between them, and the excision of the translator from that with Hanna Marton. ${ }^{49}$

Yet, just as Shoah's division into four thematic 'eras' has enabled its television broadcast, so the quartet form of The Four Sisters has suited its theatrical release, in which natural breaks occur in the unsparing four-and-a-half-hour running time. The difficulty of definitively ascribing the unusual form of The Four Sisters to its original television broadcast is clearer still if we consider Lanzmann's back catalogue, which includes another work edited for television, the first of his individual releases, A Visitor from the Living (1997). In addition, modifications have occurred over time to his chosen techniques so that, like the televisual The Four Sisters, the cinema release The Last of the Unjust (2013) uses archival photographs. Beyond even such evidence of convergence between media, and the varied 'visual and sonic choices' engendered by its particular production circumstances, The Four Sisters has a hybrid form, with its use of symbolic mise-en-scène and promotion of identification that is more usually associated with cinema. ${ }^{50}$ It is tempting to conclude that the stories of women, and the 'feminized' medium of television, both of which have been side-lined in Lanzmann's oeuvre, are here together reclaimed. ${ }^{51}$ 


\section{Notes}

1. Anne-Katrin Titze, "Survivors: David Frenkel on Claude Lanzmann's Four Sisters," Eye for Film, n.d., https://www.eyeforfilm. co.uk/feature/2018-07-08-david-frenkel-in-conversation-on-claude-lanzmann-and-the-four-sisters-les-quatre-soeursfeature-story-by-anne-katrin-titze

2. Jennifer Cazenave, An Archive of the Catastrophe: The Unused Footage of Claude Lanzmann's 'Shoah' (Albany: SUNY Press, 2019), 227.

3. Cazenave, An Archive of the Catastrophe; see also Erin McGlothlin, Brad Prager, and Markus Zisselsberger, eds., The Construction of Testimony (Detroit: Wayne State University Press, 2020) and Rémy Besson, "(Re)monter la parole des acteurs de l'histoire: Le cas de Quatre Soeurs" [Restoring a voice to the actors of history: The case of The Four Sisters], (Lanzmann 2017), March 11, 2018, https://issuu.com/remybesson/docs/gorizia

4. Raul Hilberg, in Claude Lanzmann, Shoah: The Complete Text of the Film (New York: Pantheon, 1985$), 70$.

5. See Lanzmann's discussion with André Steiner in his outtake interview about the invented agent of 'world Jewry' Ferdinand Roth, "Claude Lanzmann Shoah Collection: Interview with André Steiner," https://collections.ushmm.org/search/catalog/ irn1003919

6. Joan Ringelheim, "Women and the Holocaust: A Reconsideration of Research," Signs 10, no 4, (1985): 745.

7. Zoë Waxman, Women in the Holocaust: A Feminist History (Oxford: Oxford University Press, 2017 ), 9.

8. The outtakes were created by Claude Lanzmann during the filming of Shoah and are used and cited by permission of the United States Holocaust Memorial Museum and Yad Vashem, the Holocaust Martyrs' and Heroes' Remembrance Authority, Jerusalem.

9. Lanzmann, Shoah: The Complete Text of the Film, 16.

10. Cazenave, An Archive of the Catastrophe, 84.

11. Quoted in Bernard Edinger, "Claude Lanzmann does it again," Jerusalem Post, January 28, 2018, https://www.jpost.com/ jerusalem-report/claude-lanzmann-does-it-again-533372

12. Debarati Sanyal, "The Gender of Testimony: Ruth Elias and the Challenge to Lanzmann's Paradigm of Witnessing," in The Construction of Testimony, eds. Erin McGlothlin, Brad Prager, and Markus Zisselsberger (Detroit: Wayne State University, 2020), 328

13. See the original unedited interview, "Claude Lanzmann Shoah Collection: Interview with Ruth Elias," https://collections. ushmm.org/search/catalog/irn1003912

14. Sanyal, "The Gender of Testimony," 328.

15. Marianne Hirsch and Leo Spitzer, "Gendered Translations: Claude Lanzmann's Shoah," in Gendering War Talk, ed. Angela Woollacott (Princeton: Princeton University Press, 1993), 3-19.

16. Sanyal, "The Gender of Testimony," 319.

17. Ibid., 326, 308.

18. Ibid., 303 .

19. Ibid., 325

20. Sarah Boden, "A New Hippocratic Oath Asks Doctors to Fight Racial Injustice and Misinformation," NPR, November 4, 2020, https://www.npr.org/sections/health-shots/2020/11/04/929233492/a-new-hippocratic-oath-asks-doctors-to-fight-racialinjustice-and-misinformation?t=1618478758669

21. Robert Jay Lifton, The Nazi Doctors: Medical Killing and the Psychology of Genocide (New York: Basic Books, 2017 [1986],) 15; Michel Foucault, Society Must Be Defended: Lectures at the Collège de France, 1975-1976, trans. David Macey (London: Allen Lane 2003), 255.

22. Lifton, The Nazi Doctors, 7.

23. Charlotte Garson, review of Les Quatre Soeurs, Études March 2018, https://www.revue-etudes.com/article/les-quatresoeurs-19122, my translation.

24. Sanyal, "The Gender of Testimony," 321.

25. Beverley Chalmers, "Lessons from the Holocaust for perinatal care today," Nurse Author \& Editor, December 2019, https:// onlinelibrary.wiley.com/doi/full/10.1111/birt.12475

26. See the original, unedited interview, "Claude Lanzmann Shoah Collection: Interview with Ada Lichtman," https://collections. ushmm.org/search/catalog/irn1002782

27. Balázs Berkovits, "Critical Whiteness Studies and the 'Jewish Problem,'” Zeitschrift für kritische Sozialtheorie und Philosophie 5, no 1 (2018): 86.

28. W.E.B. Du Bois, "The Negro and the Warsaw Ghetto," Jewish Life, 6, no. 7 (May 1952): 14-15, https://europe.unc.edu/ wp-content/uploads/sites/314/2021/02/DuBois-The-Negro-and-the-Warsaw-Ghetto.pdf

29. Sara Smith and Pavithra Vasudevan, introduction to "Race, Biopolitics and the Future," Environment and Planning 35, no 2 (2017): 211.

30. Bryan Cheyette, The Ghetto: A Very Short Introduction (Oxford: Oxford University Press, 2020), 66. 
31. See the original unedited interview, "Claude Lanzmann Shoah Collection: Interview with Paula Biren," https://collections. ushmm.org/search/catalog/irn1003910

32. Tim Cole, Holocaust City: The Making of a Jewish Ghetto (London: Routledge, 2003), xii.

33. Katarzyna Person, Warsaw Ghetto Police: The Jewish Order Service during the Nazi Occupation (Ithaca: Cornell University Press, 2021), $7 \& 9$.

34. Raul Hilberg, The Destruction of the European Jews (New York: Colophon 1979 [1961]), 666. See Lanzmann's posthumous appreciation, "Raul Hilberg, Actor in Shoah," in Perspectives on the Holocaust: Essays in Honor of Raul Hilberg, eds. James S. Pacy and Alan Wertheimer (Boulder: Westview Press, 1995).

35. Markus Zisselsberger, "Challenging Shoah's Paradigms," in McGlothlin, The Construction of Testimony, 360; Dominick LaCapra, "Claude Lanzmann’s Shoah: 'Here There Is No Why,"' Critical Inquiry 23, no. 2 (1997): 234.

36. Agnieszka Wądołowska, interview with Katarzyna Person, Notes from Poland, July 16, 2020, https://notesfrompoland, com/2020/07/16/interview-jewish-ghetto-police-were-both-a-tool-and-a-victim-of-the-holocaust/

37. See the original, unedited interview, "Claude Lanzmann Shoah Collection: Interview with Hanna Marton," https://collections. ushmm.org/search/catalog/irn1003917

38. André Habib, "Delay, Estrangement, Loss: The Meanings of Translation in Claude Lanzmann's Shoah," SubStance 44, no. 2 (2015): 108-128; Francine Kaufmann, personal correspondence, November 19, 2020.

39. Gillian Rose, Mourning Becomes the Law: Philosophy and Representation (Cambridge: Cambridge University Press, 1996), 56

40. Zygmunt Bauman, Modernity and the Holocaust (Cambridge: Polity, 1989), 135

41. Ibid., 66.

42. Claude Lanzmann, The Patagonian Hare: A Memoir, trans. Frank Wynne (London: Atlantic Books, 2012 [2009]), 425.

43. Thomas B. Repine et al., "The Dynamics and Ethics of Triage: Rationing Care in Hard Times," Military Medicine 170, no. 6 (2005): 508.

44. Bauman, Modernity and the Holocaust, 69.

45. Claude Lanzmann, "Director's Statement," Shoah: The Four Sisters, booklet accompanying DVD, 39.

46. Cazenave, An Archive of the Catastrophe, 230; Lawrence Garcia, "Shoah: Four Sisters extends the legacy of Claude Lanzmann's essential film," AV Club, November 13, 2018, https://film.avclub.com/shoah-four-sisters-extends-thelegacy-of-claude-lanzma-1830374735

47. Pat Brown "Review: Shoah: Four Sisters," Slant, November 11, 2018, https://www.slantmagazine.com/film/shoah-foursisters/. The American title, Shoah: The Four Sisters, suggests a perceived need for explicit framing as part of Lanzmann's oeuvre.

48. Deborah L. Jaramillo, "Rescuing Television from the Cinematic: The Perils of Dismissing Television Style," in Television Aesthetics and Style, eds. Jason Jacobs and Steven Peacock (New York: Bloomsbury, 2013), 69.

49. Garcia, 'Shoah: Four Sisters.'

50. Jaramillo, "Rescuing Television," 73.

51. Jason Jacobs, quoted in Hannah Andrews, Television and British Cinema: Convergence and Divergence since 1990 (London: Palgrave, 2014), 15.

\section{B i o graph y}

Sue Vice is Professor of English Literature at the University of Sheffield, UK. 